\title{
New findings of Cryptophagidae (Coleoptera: Clavicornia) from Baltic amber in the unbiased collection of the Paleontological Institute of RAS
}

\section{Новые находки Cryptophagidae (Coleoptera: Clavicornia) из репрезентативной комлекщии балтийского янтаря ПИН РАН}

\author{
G.Yu. Lyubarsky ${ }^{1}$, E.E. Perkovsky ${ }^{2,3}$ \\ Г.Ю. Аюбарский ${ }^{1}$ Е.Э. Перковский ${ }^{2,3}$
}

\footnotetext{
${ }^{1}$ Zoological Museum of Moscow State University, Bol'shaya Nikitskaya str., 2, Moscow 125009, Russia. E-mail: lgeorgy@rambler.ru

${ }^{2}$ Schmalhausen Institute of Zoology, National Academy of Sciences of Ukraine, 15 Bogdan Khmelnitsky Str., Kiev 01601, Ukraine.

${ }^{3}$ A.A. Borissiak Paleontological Institute, Russian Academy of Sciences, Profsoyuznaya Str. 123, 117868 Moscow, Russia. E-mail: perkovsk@gmail.com

1 Зоологический музей МГУ, ул. Б. Никитская 2, Москва 125009, Россия.

${ }^{2}$ Институт зоологии им. И.И. Шмальгаузена НАН Украины, ул. Б. Хмельницкого, 15, Киев 01030, Украина.

3 Палеонтологический институт им. А.А. Борисяка РАН, Профсоюзная ул. 123, Москва 117997, Россия.
}

KEY WORDS: Cryptophagidae, Atomaria, Micrambe, Late Eocene, Baltic amber.

КЛЮЧЕВЫЕ СЛОВА: Cryptophagidae, Atomaria, Micrambe, поздний эоцен, балтийский янтарь.

ABSTRACT. In the Paleontological Institute's collection the two new fossil specimens of Cryptophagidae were found in Late Eocene Baltic amber. One specimen belongs to the genus Micrambe Thomson, 1863. This specimen was identified as Micrambe sarnensis Lyubarsky et Perkovsky, 2010. Earlier this species was found in Rovno amber, but the new specimen is from Baltic amber. A redescription of $M$. sarnensis is presented in this paper. An important character of the species is a large callosity occupying a quarter to a third of the lateral edge of the pronotum, and ending in a thin spike at the apex. Another specimen belongs to the genus Atomaria Stephens, 1829. This specimen was identified as $A$. groehni Perkovsky et Lyubarsky, 2014 earlier described from Baltic amber. A redescription of the species $A$. groehni is presented.

РЕЗЮМЕ. В коллекции Палеонтологического института в балтийском янтаре позднего эоцена были обнаружены два ископаемых экземпляра Cryptophagidae. Один экземпляр принадлежит к роду Micrambe Thomson, 1863 и был идентифицирован как M. sarnensis Lyubarsky et Perkovsky, 2010 ранее известного из ровенского янтаря. Важным признаком вида является крупная мозоль, занимающая от четверти до трети латерального края переднеспинки и заканчивающаяся тонким шипом на вершине. Другой экземпляр принадлежит к роду Atomaria Stephens, 1829. Этот экземпляр был идентифицирован как A. groehni Perkovsky et Lyubarsky, 2014, ранее описанный из балтийского янтаря. Приведено переописание $M$. sarnensis и $A$. groehni.

\section{Introduction}

New fossil specimens belonging to the family of Cryptophagidae were found in the collection of the Paleontological Institute RAS (PIN), Russian Academy of Sciences.

The Cryptophagidae or silken fungus beetles are a family of beetles with about 1000 described species represented in all biogeographic realms. Both adults and larvae of silken fungus beetles are commonly found on mold, fungi, under bark of trees, as well as in decaying vegetation and in the nests of social Hymenoptera, birds and mammals. Most cryptophagids are nidicolous beetles; they are one of the most abundant beetles in the nests and burrows of rodents, birds and social insects [Lyubarsky, 1996, 2002].

The first Cretaceous cryptophagid species from fossil resins was the Atomariinae Nganasania khetica Zherikhin, 1977 from Santonian Taimyr amber [Zherikhin, 1977; Lyubarsky, Perkovsky, 2014]. Then several more species and genera were described. From the Early Cretaceous of southern China Shixitomaria cretacea (Cai et Wang, 2013) was described [Cai, Wang, 2013; Lyubarsky, Perkovsky, 2018], from Albian Spanish amber Albocryptophagus cantabricus Peris et al.,

How to cite this article: Lyubarsky G.Yu., Perkovsky E. E. 2021. New findings of Cryptophagidae (Coleoptera: Clavicornia) from Baltic amber in the unbiased collection of the Paleontological Institute of RAS // Russian Entomol. J. Vol.30. No.3. P.282-287. doi: 10.15298/rusentj.30.3.05 
2017 [Peris et al., 2017]. From Santonian Taimyr amber Cryptophagini Microticus khatanga Lyubarsky et Perkovsky, 2015 and Ennoticus mnemosynon Lyubarsky et Perkovsky, 2017 [Lyubarsky, Perkovsky, 2015, 2017a] as well as atomariine Nganasania taymyrica Lyubarsky et Perkovsky, 2014 [Lyubarsky, Perkovsky, 2014].

Most paleontological findings of Cryptophagidae are from Late Eocene and Miocene [Kirejtshuk, Ponomarenko, 2014]. In Late Eocene amber the representatives of the subfamily Cryptophaginae (Antherophagus Dejean, 1821, Cryptophagus Herbst, 1792, Micrambe Thomson, 1863, Telmatophilus Heer, 1841) and Atomariinae (Atomaria Stephens, 1829, Ephistemus Stephens, 1829) have been found. The last genus is also reported from the Bitterfeld amber [Hieke, Pietrzeniuk, 1984]. These genera are reported from the Late Eocene Baltic amber found in former Eastern Prussia (now Kaliningrad region) [Klebs, 1910; Kubisz, 2001]. Latest Priabonian "Telmatophilus" britannicus Kirejtshuk et Kurochkin, 2019 [Kirejtshuk et al., 2019] from the Bembridge Marls of the UK has been transferred to Cryptophilinae (Erotylidae) as Cryptophilus britannicus (Kirejtshuk, Kurochkin, 2019). Telmatophilus sidorchukae Lyubarsky et Perkovsky was described from Priabonian Rovno amber, representing the first known Eocene species of the genus [Lyubarsky, Perkovsky, 2020]. A new genus, Spaniophagus was described from the Upper Eocene Baltic amber [Lyubarsky, Perkovsky, 2019]. The first Eocene species Micrambe from the Rovno amber was recently described as M. sarnensis by Lyubarsky et Perkovsky [Lyubarsky, Perkovsky, 2010].

So far only one species of the genus Micrambe Thomson, 1863 has been known from Rovno amber. Three species of Atomaria Stephens, 1829 have been described from Baltic and Rovno amber: A. gedanicola Lyubarsky et Perkovsky, 2013, A. groehni Perkovsky et Lyubarsky, 2014 and $A$. saxonica Lyubarsky et Perkovsky [Lyubarsky, Perkovsky, 2013, 2014, 2018]. In this work we redescribe two specimens of Cryptophagidae belonging to the genera Atomaria and Micrambe.

Photographs were taken at the Paleontological Institute, Russian Academy of Sciences by A.P. Rasnitsyn using Leica MZ 16 and by D. D. Vorontsov using the microscope Nikon Eclipse E800 with camera Olympus E-M10-II. Both specimens belong to unbiased PIN-964 collection [Dlussky, Rasnitsyn, 2009; Perkovsky, 2016].

\section{Taxonomical part}

Subfamily Cryptophaginae Kirby, 1826

Tribe Cryptophagini Kirby, 1826

Genus Micrambe Thomson, 1863

\section{Micrambe sarnensis Lyubarsky et Perkovsky, 2010 Figs 1-4.}

MATERIAL. PIN 964/1324, Baltic amber, Late Eocene. Sex: $\bigcirc^{7}$.

A new specimen of the recently described species Micrambe sarnensis was found. This allows for a more accurate description of the species, taking into account the variability.
RE-DESCRIPTION. Body broadly elongate (Fig. 1), slightly convex; head, pronotum, and elytra reddish brown. Elytra slightly convex, covered with almost appressed pubescence.

Head transverse, of normal size, with prominent, hemispherical, somewhat coarsely facetted eyes (Fig. 4), strongly and sparsely punctured. Antennae 11-segmented, long, slender, with 3-segmented club, with club reaching beyond the base of pronotum, antennomeres 1-2 elongate, twice as long as wide, $3^{\text {th }}$ slender, elongate, twice as long as wide, joint $4^{\text {th }}$ subquadrate, antennomeres 5-6 1.5 times as long as wide, joint $7^{\text {th }}$ almost equal in length, antennomere 8 slightly transverse, $9^{\text {th }}$ and $10^{\text {th }}$ transverse, $10^{\text {th }} 1.2$ times as long as wide, $11^{\text {th }}$ obliquely oval, antennomeres $9-11$ equal in width.

Pronotum distinctly transverse, barely 1.8 times broader than long, moderately strongly and densely punctured $(0.5-1$ diameter apart), an individual puncture almost equal to facette diameter. Pronotum without sublateral line, somewhat convex, slightly rounded at sides, weakly crenulate. Sides finely margined, anterior edge weakly sinuate, posterior edge with broad median lobe, emarginated.

Anterior angles of pronotum with callosity, callosity occupying about one-third or one-fourth of side margin, with a small, elongate-oval patch of bare surface invisible from above; caudolateral corner acute angular, with tip. Lateral edge crenulated, with 7-9 small teeth. Posterior corners obtuse, base round, slightly sinuate, basal groove narrow.

Tarsal formula 5-5-4, claw simple, without tooth (Figs 2-3). Last of tarsal joints longest.

Scutellum small, transverse. Elytra oval, punctuation confused, humeral corners rounded, shoulders a little broader than maximum breadth of pronotum, 1.4-1.5 times as long as wide and 2.8-2.9 times as long as thorax, moderately convex, with moderately strongly rounded sides and a narrowly rounded apex, puncturation as strong as, yet more sparse than, that on pronotum. Epipleura reduced, present beyond level of posterior margin of $1^{\text {st }}$ ventrite. Ventrite 1 longer than remaining ventrites.

Length $1.6-2.2 \mathrm{~mm}$.

REMARKS. Micrambe sarnensis was described from Rovno amber and now found in Baltic amber. The new specimen belongs to this species. The Micrambe species are very variable, the most important characters (in addition to the structure of the genitalia) are the structure of the antennae, the structure of the callosity, the relative length and width of the pronotum, and size and number of teeth on the lateral edge. This specimen slightly differs from the holotype of M. sarnensis, and is within the range of variability that can be observed, for example, in the very widespread M. abietis (Payk., 1798), distributed throughout the Palaearctic.

The most noticeable differences between specimens: slight differences in the structure of antenna, antennomeres 1-2 elongate not transverse; callosity larger than in the holotype of M.sarnensis, occupying 1/3 of lateral edge. Size of body smaller, length of the holotype of M.sarnensis $2.2 \mathrm{~mm}$.

Micrambe sarnensis is widespread in the late Eocene and in the Rovno and Baltic amber.

Subfamily Atomariinae LeConte, 1861 Tribe Atomariini LeConte, 1861

Genus Atomaria Stephens, 1829

Subgenus Anchicera Thomson, 1863

A. groehni Perkovsky et Lyubarsky, 2014 Figs 5-6.

MATERIAL. PIN 964/1325, Baltic amber, Late Eocene. Spec- 
imen is deposited in the amber collection of the PIN RAS. Sex: unknown.

RE-DESCRIPTION. Length of body $1.0-1.1 \mathrm{~mm}$, body elongate (Figs 5-6), moderately arched, head, pronotum, and elytra light-brown. Elytra slightly convex, covered with slightly curved long elevated pubescence.

Head transverse, of normal size, with hemispherical facetted eyes, strongly punctured. Antennae moderately long, with club reaching beyond base of pronotum, flagellomeres slightly elongate, antennomeres $1^{\text {st }}, 2^{\text {nd }}$ about 1.5 times as long as broad, $3^{\text {rd }}$ slightly elongate, $4^{\text {th }}$ and $6^{\text {th }}$ antennomeres as long as broad, $5^{\text {th }} 1.5$ times as long as broad, $7^{\text {th }}, 8^{\text {th }}$ subquadrate, $9^{\text {th }}$ slightly transverse, $10^{\text {th }}$ strongly transverse, $11^{\text {th }}$ obliquely oval, antennomeres 9-11 equal in width. Antennae inserted under the lateral margin of the forehead, widely separated basally, antennal insertions close to the eyes.

Pronotum convex, not narrowed basally, slightly transverse, 1.2-1.5 times broader than long, broadest before the middle, moderately strongly and very densely punctured (distance between punctures equal to their diameter), a single puncture smaller than the diameter of the eye facet. Pubescence long and elevated. Sides finely margined, anterior edge

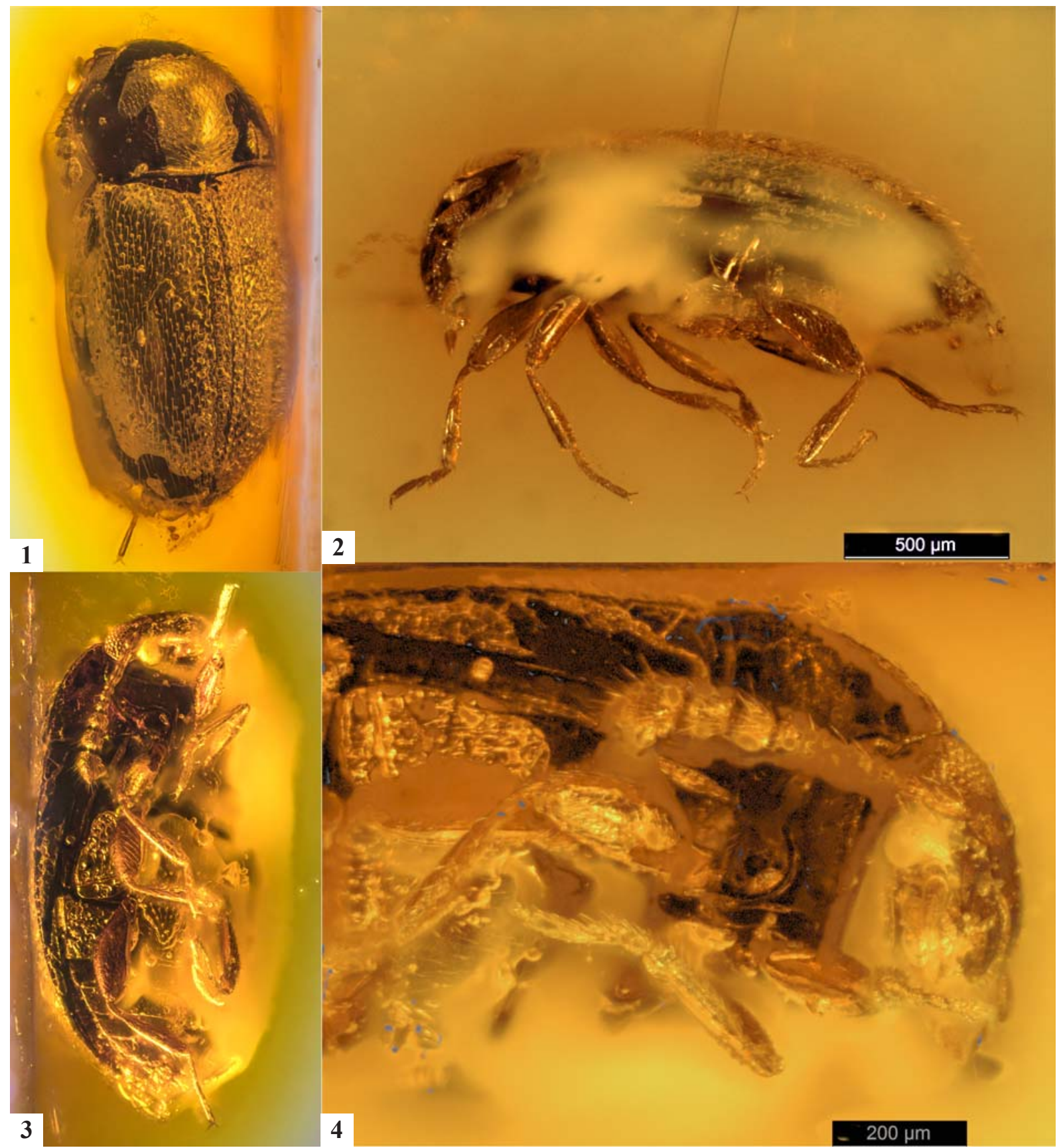

Figs 1-4. Photo of a new specimen of M. sarnensis from Baltic amber: 1 - dorsal view; 2 - lateral view; 3 - ventral view; 4 - head and pronotum, ventrolateral view.

Рис. 1-4. Внешний вид M. sarnensis из балтийского янтаря: 1 - габитус, сверху; 2 - габитус, сбоку; 3 - габитус,снизу; 4 голова и переднеспинка, снизу и сбоку. 
weakly sinuate, without excision. Pronotum broadest before middle of its length. Side borders visible from above along the entire length. Lateral margin without callosity. Posterior corners right angled, basal edge lobed, strongly sinuate, basal groove shallow.
Scutellum small, transverse. Elytra short-oval, moderately convex, humeral corners rounded, maximum breadth of elytra in first third of their length, 1.6-1.7 times as long as wide and 2.5-2.7 times as long as thorax, punctuation slightly stronger and sparser than that on pronotum. Punctures in

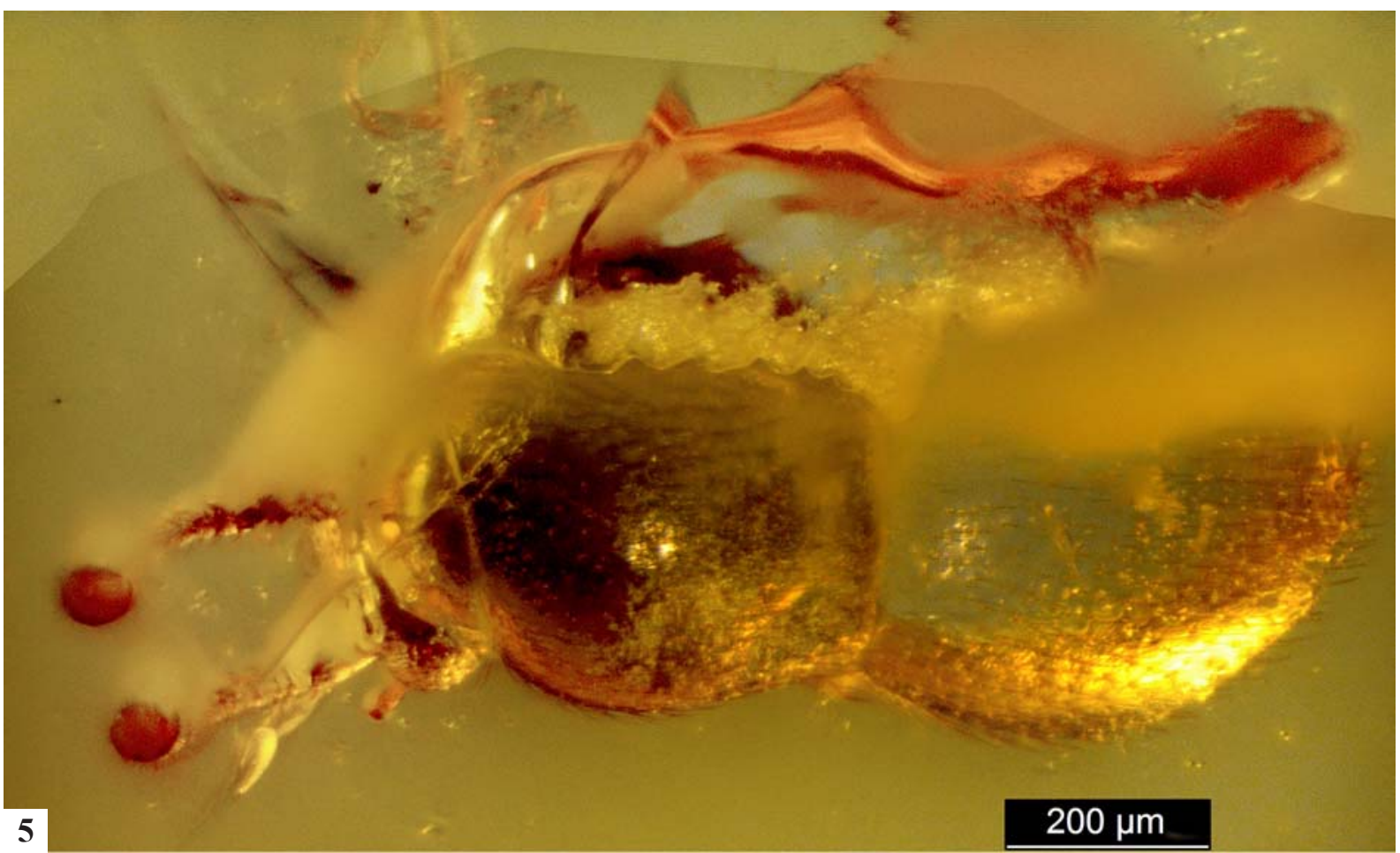

5

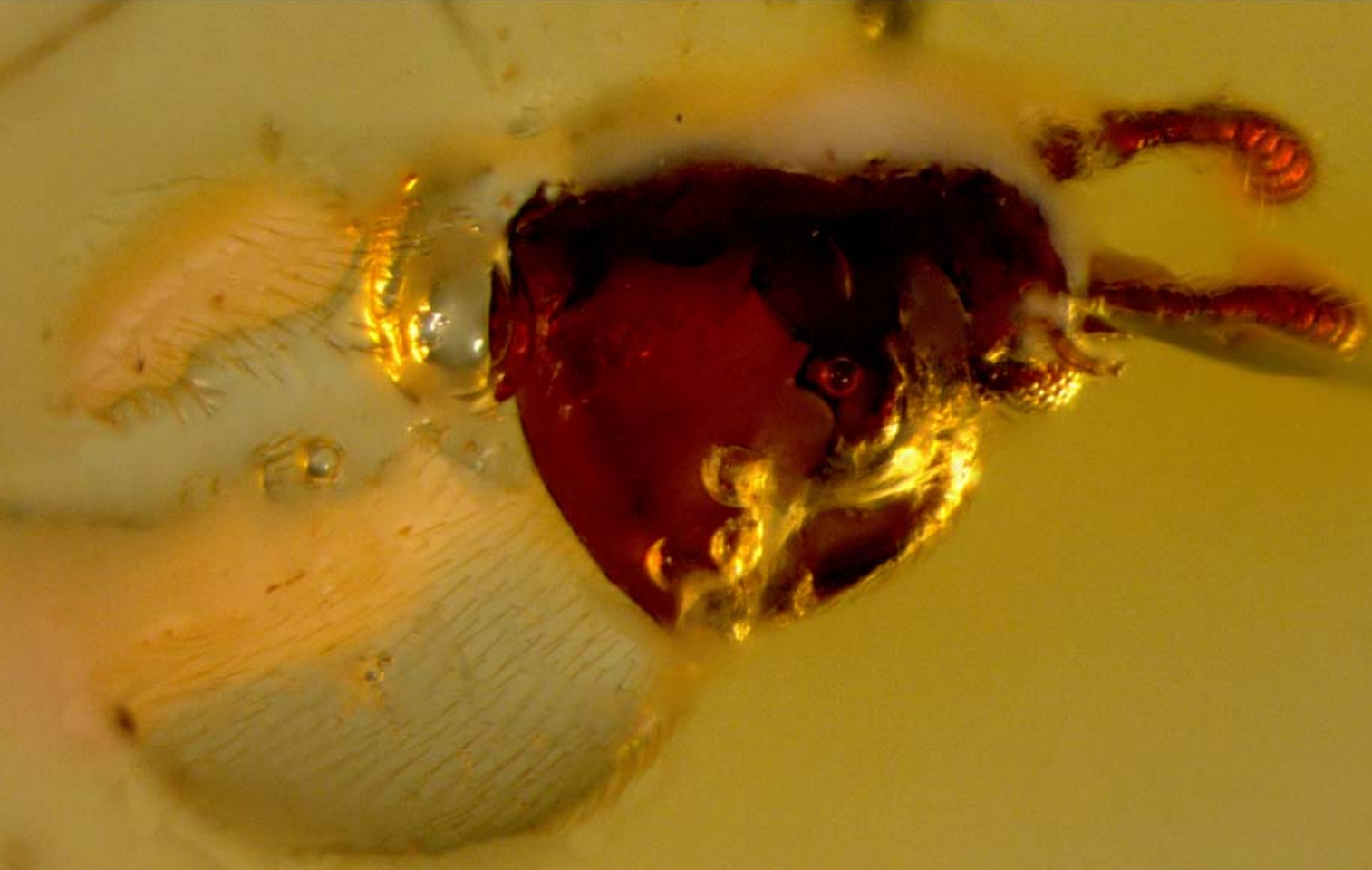

6

Figs 5-6. Photo of a new specimen of A. groehni from Baltic amber: 5 - dorsal view; 6 - dorsolateral view.

Рис. 5-6. Внешний вид A. groehni из балтийского янтаря: 5 - сверху; 6 - сверху и сбоку. 
the basal part slightly stronger than those on the pronotal disk, and approximately 1.5-2 diameters apart from their lateral neighbours on an average; humeri not toothed.

REMARKS. Representatives of Atomaria are found in all biogeographic realms including 127 species in the Palaearctic Region [Johnson et al., 2007].

Atomaria groehni differs from similar species with lateral margin of pronotum visible from above, such as A. morio Kolenati, 1846 and $A$. versicolor Erichson, 1846, by small size and long elevated pubescence. A. groehni differs from species similar to $A$. testacea Stephens, 1830 in pronotum slightly narrowed basally and small size. A. groehni differs from most species of the genus in the structure of the antenna: the segments of the flagellum are subquadrate or slightly elongate.

Among the species of amber, it differs in a combination of characters: pronotum broadest before the middle of its length; elytra covered by long elevated pubescence; side borders of pronotum visible from above along the entire length.

\section{Discussion}

In all Priabonian ambers the domination of Holarctic elements is strong [Perkovsky, 2017; Radchenko, Perkovsky, 2021], but in the Baltic amber it is most evident. Ambers from southern coast of Subparathetys differ in the better representation of thermophilic species (tropical element) [Perkovsky, Olmi, 2018; Colombo et al., 2020; Lyubarsky, Perkovsky, 2017b]. Better studied Hymenoptera from Rovno amber include less than $49 \%$ species known from Baltic amber [Simutnik et al., 2020; Colombo et al., 2021; Radchenko et al., 2021], Nematocera - $24 \%$ of such species [Gilka et al., 2021].

Among Rovno beetles only $13 \%$ are species known from Baltic amber [Kupryjanowicz et al., 2021; Legalov et al., 2021; Kirichenko-Babko et al., 2021; this paper]; as was supposed [Bukejs et al., 2020] many Baltic beetles would be found in Rovno amber, as is the case with Bitterfeld amber [Bukejs et al., 2016], however it is highly likely that some Holarctic taxa from Baltic amber were absent in Rovno fauna (and A. groehni could belong to this group). On the other hand, some beetles from Holarctic genera, described from Rovno amber, can be found in Baltic amber, as Crepidodera [Bukejs et al., 2016] and Micrambe sarnensis.

Acknowledgements. Authors are obliged to D.D. Vorontsov (Moscow) for cutting and pics of Micrambe, and A.P. Rasnitsyn (PIN) for pics of Atomaria. The study was supported by the research project "Taxonomic and Biochorologic Analysis of the Animal Kingdom as the Basis for the Study and Preservation of the Structure of Biodiversity" (AAAAA16-116021660077-3), Zoological Museum of Moscow State University, for the first author.

Competing interests. The authors declare no competing interests.

\section{References}

Bukejs A., Biondi M., Alekseev V.I. 2016. New records and species of Crepidodera Chevrolat (Coleoptera: Chrysomelidae) in Eocene European amber, with a brief review of described fossil beetles from Bitterfeld amber // Zootaxa. Vol.4193. No.2. P.390-400. https://doi.org/10.11646/zootaxa.4193.2.13.

Bukejs A., Háva J., Alekseev V.I. 2020. A new fossil species of Attagenus Latreille (Coleoptera: Dermestidae) in Rovno and Baltic ambers, with a brief review of known fossil beetles from the Rovno amber Lagerstätte // Fossil Record. Vol.23. P.95104. https://doi.org/10.5194/fr-23-95-2020.

Cai C.-Y., Wang B., 2013. The oldest silken fungus beetle from the Early Cretaceous of southern China (Coleoptera: Cryptophagidae: Atomariinae) // Alcheringa. Vol.37. P.452-455.

Colombo W.D., Gobbi F.T., Perkovsky E.E., Azevedo C.O. 2020. Synopsis of the fossil Pristocerinae (Hymenoptera, Bethylidae), with description of two new genera and species from Burmese, Taimyr, Baltic and Rovno ambers // Historical Biology. [published online: 13 Mar 2020]. https://doi.org/10.1080/08912963. 2020.1733551.

Colombo W.D., Perkovsky E.E., Waichert C., Azevedo C.O. 2021. Synopsis of the fossil flat wasps Epyrinae (Hymenoptera, Bethylidae), with description of three new genera and ten new species // Journal of Systematic Palaeontology. Vol.19. No.1. P.39-89.

Dlussky G.M., Rasnitsyn A.P. 2009. Ants (Insecta: Vespida: Formicidae) in the Upper Eocene amber of Central and Eastern Europe // Paleontological Journal. Vol.43. No.9. P.1024-1042. https:// doi.org/10.1134/S0031030109090056.

Gilka W., Harbach R.E., Perkovsky E.E. 2021. Mosquitoes (Diptera: Culicidae) in Eocene amber from the Rovno region, Ukraine // Zootaxa. Vol.5016. No.2. P.257-270. https://doi.org/10.11646/ zootaxa.5016.2.6.

Hieke F., Pietrzeniuk E. 1984. Die Bernstein-Käfer des Museums für Naturkunde, Berlin (Insecta, Coleoptera) // Mitt. zool. Mus. Berl. Bd.60. H.2. S.297-326.

Johnson C., Otero J.C., Leschen R.A.B. 2007. Family Cryptophagidae // Löbl I., Smetana A. (eds.). A catalogue of Palaearctic Coleoptera. Vol.4. Steenstrup: Apollo Books. P.513-531.

Kirejtshuk A.G., Ponomarenko A.G. 2014. Systematicheskiy spisok iskopaemykh zhukov podotryada Scarabaeina (3rd part of catalogue). http://www.zin.ru/animalia/coleoptera/rus/paleosy2.htm Kirejtshuk A.G., Ponomarenko A.G., Kurochkin A.S., Alexeev A.V., Gratshev V.G., Solodovnikov A.Yu., Krell F.-Th., Soriano C. 2019. The beetle (Coleoptera) fauna of the Insect Limestone (late Eocene), Isle of Wight, southern England // Earth and Environmental Science Transactions of the Royal Society of Edinburgh. Vol.110. Nos 3-4. P.405-492.

Kirichenko-Babko M., Perkovsky E.E., Vasilenko D.V. 2021. A new genus and species of Lebiini (Coleoptera: Carabidae) from late Eocene Rovno amber // Historical Biology. [published online: 21 Jul 2021]. https://doi.org/10.1080/08912963.2021.1924701

Klebs R. 1910. Über Bersteineinschlusse im allgemeinen und die Coleopteren meiner Bernsteinsammlung // Schriften der physikalisch-ökonomischen Gesellschaft zu Königsberg i Pr. Bd.5. S.217-242.

Kubisz D. 2001. Beetles in the collection of the Museum of Amber Inclusions, University of Gdansk, with description of Colotes sambicus sp. n. (Coleoptera: Melyridae) // Polskie Pismo Entomologiczne. Vol.70. P.259-265.

Kupryjanowicz J., Lyubarsky G.Yu., Perkovsky E.E. 2021. Heterhelus buzina sp.n. (Coleoptera: Kateretidae) from Rovno amber: the first proxy for Sambucus in the Eocene of Eastern Europe // Invertebrate Zoology. Vol.18. No.1. P.16-24.

Legalov A.A., Nazarenko V.Yu., Perkovsky E.E. 2021. A new species of the genus Glaesotropis Gratshev et Zherikhin, 1995 (Coleoptera, Anthribidae) from Rovno amber // Fossil Record. Vol.24. No.1. P.1-7. https://doi.org/10.5194/fr-24-1-2021.

Lyubarsky G.Yu. 1996. [Archetype, Style, and Rank in Biological Systematics]. Moscow: KMK Scientific Press. 430 pp. [In Russian]

Lyubarsky G.Yu. 2002. [Cryptophaginae (Coleoptera: Cucujoidea: Cryptophagidae): Diagnostics, Arealogy, Ecology] // Sbornik trudov Zoologicheskogo Muzeya MGU. T.43. Moscow. Moscow State University Press. 421 pp. [In Russian]

Lyubarsky G.Yu., Perkovsky E.E. 2010. The first Eocene species of the genus Micrambe (Coleoptera, Clavicornia, Cryptophagidae) // Vestnik zoologii. Vol.44. No.3. P.275-279.

Lyubarsky G.Yu., Perkovsky E.E. 2013. Fourth contribution on Late Eocene amber silken fungus beetles: a new Baltic amber species of Atomaria (Coleoptera, Clavicornia, Cryptophagidae) // Vestnik zoologii. Vol.47. No.3. P.63-66.

Lyubarsky G.Yu., Perkovsky E.E. 2014. New species of the genus 
Nganasania from Upper Cretaceous of Taymyr (Coleoptera: Cryptophagidae)// Russian Entomol. J. Vol.23. No.3. P.191-194.

Lyubarsky G.Yu., Perkovsky E.E. 2015. New genus Microticus from Upper Cretaceous of Taymyr (Coleoptera: Cryptophagidae), oldest silken fungus beetle with sexually dimorphic tarsal formula // Russian Entomol. J. Vol.24. No.1. P.61-66.

Lyubarsky G.Yu., Perkovsky E.E. 2017a. New genus Ennoticus from the Upper Cretaceous of Taimyr (Coleoptera: Cryptophagidae) // Paleontological Journal. Vol.51. No.2. P.191-195.

Lyubarsky G.Yu., Perkovsky E.E. 2017b. Serramorphus, a new genus of Erotylidae from Eocene amber (Coleoptera: Clavicornia) from Late Eocene Bitterfeldian Amber // Russian Entomol. J. Vol.26. No.1. P.37-40.

Lyubarsky G.Yu., Perkovsky E.E. 2018. First species of Atomaria (Coleoptera: Clavicornia: Cryptophagidae) from Bitterfeld amber and several notes on Miocene and Cretaceous Cryptophagidae // Russian Entomol. J. Vol.27. No.4. P.381-385.

Lyubarsky G.Yu., Perkovsky E.E. 2019. Spaniophagus, first new Eocene genus of silken fungus beetle from Baltic amber (Coleoptera: Clavicornia: Cryptophagidae) // Russian Entomol. J. Vol.28. No.3. P.263-268. doi: 10.15298/rusentj.28.3.05.

Lyubarsky G.Yu., Perkovsky E.E. 2020. First Rovno amber species of the genus Telmatophilus (Coleoptera: Clavicornia: Cryptophagidae) from Veselukha floodplain//Invertebrate Zoology. Vol.17. No.1. P.25-35. https://doi.org/10.15298/invertzool.17.1.03.

Peris D., Lyubarsky G.Yu., Perkovsky E.E. 2017. A new genus of silken-fungus beetle (Coleoptera: Cryptophagidae) from the Spanish Cretaceous amber // Cretaceous Research. Vol.78. P.191-195. https://doi.org/10.1016/j.cretres.2017.06.018.

Perkovsky E.E. 2016. Tropical and Holarctic ants in Late Eocene ambers // Vestnik zoologii. Vol.50. No.2. P.111-122. https:// doi.org/10.1515/vzoo-2016-0014.

Perkovsky E.E. 2017. Comparison of biting midges of the Early Eocene Cambay amber (India) and Late Eocene European ambers supports the independent origin of European ambers // Vestnik Zoologii. Vol.51. P.275-284.

Perkovsky E.E., Lyubarsky G.Yu. 2014. Fifth contribution on silken fungus beetles from Late Eocene amber: a second Baltic amber species of Atomaria (Coleoptera: Clavicornia: Cryptophagidae) // Russian Entomol. J. Vol.23. No.1. P.41-44.

Perkovsky E.E., Olmi M. 2018. Discovery of the first pincer wasp (Hymenoptera, Dryinidae) from Rovno amber // Zootaxa. Vol.4457. No.2. P.296-304.

Radchenko A.G., Perkovsky E.E. 2021. Wheeler's dilemma revisited: first Oecophylla-Lasius syninclusion and other ants syninclusions in the Bitterfeld amber (late Eocene) // Invertebrate Zoology. Vol.18. No.1. P.47-65.

Radchenko A.G., Perkovsky E.E., Vasilenko D.V. 2021. Formica species (Hymenoptera, Formicidae, Formicinae) in late Eocene Rovno amber // Journal of Hymenoptera Research. Vol.82. P.237-251.

Simutnik S.A., Perkovsky E.E., Vasilenko D.V. 2020. First record of Leptoomus janzeni Gibson (Hymenoptera, Chalcidoidea) from Rovno amber // Journal of Hymenoptera Research. Vol.80. P.137-145.

Zherikhin V.V. 1977. [Families Cerophytidae, Acanthocnemidae, Cryptophagidae, Lathridiidae, Attelabidae, Curculionidae] // B.B. Rodendorf (ed.). Mezozoiskie zhestkokrylye. Trudy Paleontologicheskogo Instituta AN SSSR. Vol.161. P.130-134, 135-142, 176-182 [in Russian]. 